\title{
Sensitization of ASIC3 by proteinase- activated receptor 2 signaling contributes to acidosis-induced nociception
}

\author{
Jing Wu', Ting-Ting Liư ${ }^{1,2}$, Yi-Mei Zhou' ${ }^{1}$ Chun-Yu Qiü ${ }^{3}$, Ping Ren ${ }^{3}$, Ming Jiao ${ }^{1 *}$ and Wang-Ping $\mathrm{Hu}^{1,2^{*}}$
}

\begin{abstract}
Background: Tissue acidosis and inflammatory mediators play critical roles in pain. Pro-inflammatory agents trypsin and tryptase cleave and activate proteinase-activated receptor $2\left(\mathrm{PAR}_{2}\right)$ expressed on sensory nerves, which is involved in peripheral mechanisms of inflammation and pain. Extracellular acidosis activates acid-sensing ion channel 3 (ASIC3) to trigger pain sensation. Here, we show that a functional interaction of $\mathrm{PAR}_{2}$ and ASIC3 could contribute to acidosisinduced nociception.
\end{abstract}

Methods: Electrophysiological experiments were performed on both rat DRG neurons and Chinese hamster ovary (CHO) cells expressing ASIC3 and PAR . Nociceptive behavior was induced by acetic acid in rats.

Results: PAR $-A P, P A R_{2}$-activating peptide, concentration-dependently increased the ASIC3 currents in CHO cells transfected with $A S I C 3$ and $\mathrm{PAR}_{2}$. The proton concentration-response relationship was not changed, but that the maximal response increased $58.7 \pm 3.8 \%$ after pretreatment of $\mathrm{PAR}_{2}-\mathrm{AP}$. PAR $\mathrm{R}_{2}$ mediated the potentiation of ASIC3 currents via an intracellular cascade. PAR $-A P$ potentiation of ASIC3 currents disappeared after inhibition of intracellular G protein, PLC, PKC, or PKA signaling. Moreover, $\mathrm{PAR}_{2}$ activation increased proton-evoked currents and spikes mediated by ASIC3 in rat dorsal root ganglion neurons. Finally, peripheral administration of PAR ${ }_{2}-A P$ dose-dependently exacerbated acidosis-induced nocifensive behaviors in rats.

Conclusions: These results indicated that $\mathrm{PAR}_{2}$ signaling sensitized ASIC3, which may contribute to acidosis-induced nociception. These represent a novel peripheral mechanism underlying PAR $\mathrm{P}_{2}$ involvement in hyperalgesia by sensitizing ASIC3 in primary sensory neurons.

Keywords: Proteinase-activated receptor 2, Acid-sensing ion channel 3, Proton-gated current, Nociception, Dorsal root ganglion neuron

\section{Background}

Proteinase-activated receptors (PARs) are a subfamily of G protein-coupled receptors (GPCRs) and have at least four members $\left(\mathrm{PAR}_{1}, \mathrm{PAR}_{2}, \mathrm{PAR}_{3}\right.$, and $\left.\mathrm{PAR}_{4}\right)$ [1]. PARs can be activated by several proteases such as trypsin and tryptase, which are generated during tissue injury and inflammation [2]. These proteases cleave PARs at a specific site within the extracellular amino-terminus and subsequently expose amino-terminal to the tethered ligand domain that binds to and activates the cleaved receptors [3]. Some specific

\footnotetext{
* Correspondence: songflower@163.com; wangping_hu@163.com

${ }^{1}$ Research Center of Basic Medical Sciences, School of Basic Medical Sciences, Hubei University of Science and Technology, 88 Xianning Road, Xianning 437100, Hubei, People's Republic of China

Full list of author information is available at the end of the article
}

synthetic peptides have been shown to activate the specific PARs and mimic the effects of the activating proteases. For example, 2-furoyl-LIGRLO-NH2 and SLIGKV-NH2 are used for $\mathrm{PAR}_{2}$ activation [4]. Once activated, PARs regulate multiple pathophysiological processes including inflammation, pain, hemostasis, and healing $[2,5,6]$. It has been found that $\mathrm{PAR}_{2}$ is expressed on a subset of primary sensory neurons and functionally involved in peripheral mechanisms of inflammation and pain $[7,8]$. $\mathrm{PAR}_{2}$ is co-localized with substance $\mathrm{P}$ and calcitonin generelated peptide in over $60 \%$ of dorsal root ganglion (DRG) neurons, and activation of $\mathrm{PAR}_{2}$ on sensory nerve ending evokes the release of these peptides in peripheral tissues [7]. Intraplantar injection of subinflammatory doses of 
$\mathrm{PAR}_{2}$ agonists in rats and mice induces thermal and mechanical hyperalgesia [9]. $\mathrm{PAR}_{2}$-deficient mice fail to show nociceptive sensitization in many inflammatory pain models [9]. In addition, $\mathrm{PAR}_{2}$ is found to play an important role in postoperative, neuropathic, and cancer pain $[6,10-12] . \mathrm{PAR}_{2}$ signaling is sufficient to induce the transition to a chronic pain state [13]. It is reported that $\mathrm{PAR}_{2}$ activation can sensitize rat DRG neurons in vitro and may contribute to the pathogenesis of pain $[7$, 8]. $\mathrm{PAR}_{2}$ activation leads also to sensitization of transient receptor potential (TRP) channels, including TRPV1, TRPV4, and TRPA1, which are crucial for nociceptive signaling and modulation. It has been demonstrated that thermal hyperalgesia induced by intraplantar injection of $\mathrm{PAR}_{2}$ agonist is dependent on TRPV1 activation $[10,14,15]$. Mechanical hyperalgesia evoked by peripheral activation of $\mathrm{PAR}_{2}$ is prevented in TRPV4 knock-out mice [16, 17]. Sensitization of TRPA1 by PAR $_{2}$ activation contributes to inflammatory pain and paclitaxel-induced mechanical, heat, and cold hypersensitivity $[10,18]$. Thus, TRPV1, TRPV4, and TRPA1 mediate the pronociceptive actions of $\mathrm{PAR}_{2}$.

Acid-sensing ion channels (ASICs) are proton-gated cation channels which are activated by extracellular $\mathrm{pH}$ fall. To date, at least six ASIC subunits encoded by four genes have been identified in mammals [19]. Most of the ASIC subunits (i.e., ASIC1a and b, ASIC2a and b, and ASIC3) are expressed in both DRG cell bodies and sensory terminals, which contribute to proton-evoked pain signaling [20-22]. It has been demonstrated that application of an acidic solution into the skin depolarizes the terminals of nociceptive primary sensory neurons to cause pain sensation by activating ASICs, rather than TRPV1 [21, 23]. Among the ASIC subunits, ASIC3 displays higher sensitivity to extracellular protons than other ASICs, with activation thresholds just below the physiological $\mathrm{pH}$ value (around pH 7.2) [24]. During inflammation, tissue injury, ischemic stroke, and surgical trauma, proton is released and decreases extracellular $\mathrm{pH}$ level [25]. The released proton is sufficient to activate ASIC3 and can trigger pain sensation [26]. ASIC3 is specifically localized in nociceptive fibers innervating the skeletal and cardiac muscles, joints, and bone [27, 28]. Activation of ASIC3 in sensory neurons has been proposed to contribute to the generation of pain. Blocking ASIC3 at the periphery inhibits the spontaneous pain generated by mild cutaneous acidification, reverses CFA-induced primary hyperalgesia, and reduces post-operative pain behaviors when applied to the incised area during surgery $[21,29,30]$. Increasing evidence has shown that ASIC3 plays an important role in various pain conditions such as inflammatory pain, postoperative pain, and migraine [22, 29,31].

We report here a functional interaction between $\mathrm{PAR}_{2}$ and ASIC3 in both rat DRG neurons and Chinese hamster ovary $(\mathrm{CHO})$ cells expressing ASIC3 and $\mathrm{PAR}_{2}$, which contributes to acidosis-induced nociception in rats.

\section{Methods \\ Cell culture and transfection}

ASIC3, ASIC1a, ASIC1b, ASIC2b, and $\mathrm{PAR}_{2}$ complementary DNAs (cDNAs) were used for heterologous expression in $\mathrm{CHO}$ cells as described previously (Wang et al., 2013). In brief, $\mathrm{CHO}$ cells were cultured at $37^{\circ} \mathrm{C}$ in a humidified atmosphere of $5 \% \mathrm{CO}_{2}$ and $95 \% \mathrm{O}_{2}$ and passaged twice a week. Transient transfection of $\mathrm{CHO}$ cells was performed using HilyMax liposome transfection reagent (Dojindo Laboratories). CHO cells were maintained in F-12 Nutrient Mixture (added $1.176 \mathrm{~g}$ of $\mathrm{NaHCO}_{3} / \mathrm{L}$ medium) supplemented with $10 \%$ fetal bovine serum and $1 \%$ glutaMAXTM-1 (100x; Invitrogen). When ASIC3 and PAR 2 cDNAs were co-transfected, the ratio was kept at 1:1. All plasmids used contained, in addition to the desired ASIC3 cDNA, the coding sequence for enhanced green fluorescent protein to aid identification of transfected cells. Electrophysiological measurements were performed 24-48 h after transfection.

\section{Isolation of DRG neurons}

The experimental protocol was approved by the animal research ethics committee of Hubei University of Science and Technology (No. 2016-67). All procedures conformed to international guidelines on the ethical use of animals, and every effort was made to minimize the number of animals used and their sufferings. Five- to 6-weekold Sprague-Dawley male rats were anesthetized with 7\% chloral hydrate and then decapitated. The DRGs were taken out and transferred immediately into Dulbecco's modified Eagle's medium (DMEM, Sigma) at pH 7.4. After the removal of the surrounding connective tissues, the DRGs were minced with fine spring scissors and the ganglion fragments were placed in a flask containing $5 \mathrm{ml}$ of DMEM in which trypsin (type II-S, Sigma) $0.5 \mathrm{mg} / \mathrm{ml}$, collagenase (type I-A, Sigma) $1.0 \mathrm{mg} / \mathrm{ml}$, and DNase (type IV, Sigma) $0.1 \mathrm{mg} / \mathrm{ml}$ had been dissolved and incubated at $35{ }^{\circ} \mathrm{C}$ in a shaking water bath for $25-30 \mathrm{~min}$. Soybean trypsin inhibitor (type II-S, Sigma) $1.25 \mathrm{mg} / \mathrm{ml}$ was then added to stop trypsin digestion. The incubating solution was then replaced by external solution. Dissociated neurons were placed into a $35-\mathrm{mm}$ Petri dish and kept for at least $1 \mathrm{~h}$ in normal external solution before the start of electrophysiological experiments. After plating of the DRG neurons, the neurons were used for experiments within $24 \mathrm{~h}$. The neurons selected for electrophysiological experiment were $15-35 \mu \mathrm{m}$ in diameter.

\section{Electrophysiological recordings}

Whole-cell patch clamp and voltage clamp recordings were carried out at room temperature $\left(22-25{ }^{\circ} \mathrm{C}\right)$ using a 
MultiClamp-700B amplifier and Digidata-1440A A/D converter (Axon Instruments, CA, USA). Recording pipettes were pulled using a Sutter P-97 puller (Sutter Instruments, CA, USA). The micropipettes were filled with internal solution containing $(\mathrm{mM}) \mathrm{KCl} 140, \mathrm{MgCl}_{2} 2.5$, HEPES 10, EGTA 11, and ATP 5; its pH was adjusted to 7.2 with $\mathrm{KOH}$, and osmolarity was adjusted to $310 \mathrm{mOsm} / \mathrm{L}$ with sucrose. Cells were bathed in an external solution containing $(\mathrm{mM}) \mathrm{NaCl} 150, \mathrm{KCl} 5, \mathrm{CaCl}_{2} 2.5, \mathrm{MgCl}_{2} 2$, HEPES 10, D-glucose 10; its osmolarity was adjusted to $330 \mathrm{mOsm} / \mathrm{L}$ with sucrose and its $\mathrm{pH}$ to 7.4. The resistance of the recording pipette was in the range of 3-6 M $\Omega$. A small patch of membrane underneath the tip of the pipette was aspirated to form a giga seal, and then, a negative pressure was applied to rupture it, thus establishing a whole-cell configuration. The series resistance was compensated for by $70-80 \%$. The adjustment of capacitance compensation was also done before recording the membrane currents. The membrane voltage was maintained at $-60 \mathrm{mV}$ in all voltage clamp experiments unless otherwise specified. Current clamp recordings were obtained by switching to current clamp mode after a stable whole-cell configuration was formed in voltage clamp mode. Only cells with a stable resting membrane potential (more negative than $-50 \mathrm{mV}$ ) were used in the study. Signals were sampled at 10 to $50 \mathrm{kHz}$ and filtered at 2 to $10 \mathrm{kHz}$, and the data were stored in compatible PC computer for off-online analysis using the pCLAMP 10 acquisition software (Axon Instruments, CA, USA).

\section{Drug application}

Drugs purchased from Sigma and used in the experiments include hydrochloric acid, 2-furoyl-LIGRLO-NH2 (a $\mathrm{PAR}_{2}$-activating peptide $\left(\mathrm{PAR}_{2}\right.$-AP)), trypsin, FSLLRY$\mathrm{NH} 2$, APETx2, and capsazepine. Different $\mathrm{pH}$ values were configured with hydrochloric acid and external solution. All drugs were dissolved daily in the external solution just before use and held in a linear array of fused silica tubes (o.d./i.d. $=500 \mu \mathrm{m} / 200 \mu \mathrm{m}$ ) connected to a series of independent reservoirs. The application pipette tips were positioned $\sim 30 \mu \mathrm{m}$ away from the recorded neurons. The application of each drug was driven by gravity and controlled by the corresponding valve, and rapid solution exchange could be achieved within about $100 \mathrm{~ms}$ by shifting the tubes horizontally with a PCcontrolled micromanipulator. Cells were constantly bathed in normal external solution flowing from one tube connected to a larger reservoir between drug applications. In some experiments where GDP- $\beta$-S (Sigma), U-73122(Sigma), and GF109203X (RBI) were applied for intracellular dialysis through recording patch pipettes, they were dissolved in the internal solution before use. To ensure that the cell interior was perfused with the dialysis drug, there was at least a 30-min interval between the establishment of whole-cell access and the current measurement.

\section{Nociceptive behavior induced by acetic acid in rats}

Rats were placed in a $30 \times 30 \times 30 \mathrm{~cm}$ Plexiglas chamber and allowed to habituate for at least $30 \mathrm{~min}$ before nociceptive behavior experiments. A blind experiment was carried out. Separate groups of rats were coded and pretreated with $20 \mu \mathrm{l}$ capsazepine $(100 \mu \mathrm{M})$ together with vehicle and different dosages of $\mathrm{PAR}_{2}$-AP, FSLLRY-NH2, or APETx2 in the ipsilateral hind paw before injection of acetic acid. After $5 \mathrm{~min}$, the other experimenters who did not know the above experimental condition subcutaneously administered acetic acid solution $(0.6 \%, 20 \mu \mathrm{l})$ into the dorsal face of the hind paw using a 30-gauge needle connected to a $100-\mu \mathrm{l}$ Hamilton syringe. And nociceptive behavior (that is, number of flinches) was counted over a 5 -min period starting immediately after the injection [21,32].

\section{Data analysis}

Data were statistically compared using the Student's $t$ test or analysis of variance (ANOVA), followed by Bonferroni's post hoc test. Statistical analysis of concentration-response data was performed using nonlinear curve-fitting program ALLFIT. Data are expressed as mean \pm SEM.

\section{Results}

Enhancement of proton-gated currents by $\mathrm{PAR}_{\mathbf{2}}$ agonist in $\mathrm{CHO}$ cells co-expressing $\mathrm{ASIC} 3$ and $\mathrm{PAR}_{2}$

To investigate the functional interaction of the ASIC3 with $\mathrm{PAR}_{2}, \mathrm{ASIC} 3$ and $\mathrm{PAR}_{2}$ cDNAs were co-transfected into $\mathrm{CHO}$ cells in the present study. We first examined the effects of a $\mathrm{PAR}_{2}$-activating peptide $\left(\mathrm{PAR}_{2}\right.$-AP: 2-furoylLIGRLO-NH2) on the proton-gated currents in $\mathrm{CHO}$ cells co-expressing ASIC3 and $\mathrm{PAR}_{2}$ using a whole-cell patch clamp technique. A rapid reduction of extracellular $\mathrm{pH}$ from 7.4 to 6.6 for $5 \mathrm{~s}$ evoked an inward current $\left(I_{\mathrm{pH}}\right.$ 6.6 $)$ in $\mathrm{CHO}$ cells transfected with ASIC3 and $\mathrm{PAR}_{2}$ under the voltage clamp conditions. These acidosis-evoked currents were characterized by a large transient peak current followed by fast inactivation and then a small sustained current with no or very slow inactivation (Fig. 1a) [33]. APETx2 (500 nM), an ASIC3 blocker, inhibited the peak ASIC current without affecting the sustained plateau; thus, they may be considered to be ASIC3 currents (Fig. 1a). In addition, a pH 6.6 acidic stimulus did not induce any significant current in untransfected $\mathrm{CHO}$ cells (data not shown).

We observed that transient peak ASIC3 currents were enhanced by the pre-application of $\mathrm{PAR}_{2}$-AP for $1 \mathrm{~min}$ (Fig. 1b, c). And the potentiation of transient peak ASIC3 currents was dependent upon the concentration of $\mathrm{PAR}_{2}$ AP. Figure $1 \mathrm{~b}$ shows that the peak amplitude of $I_{\mathrm{pH}} 6.6 \mathrm{in}$ creased as concentration of pre-treated $\mathrm{PAR}_{2}$ - $\mathrm{AP}$ increased 

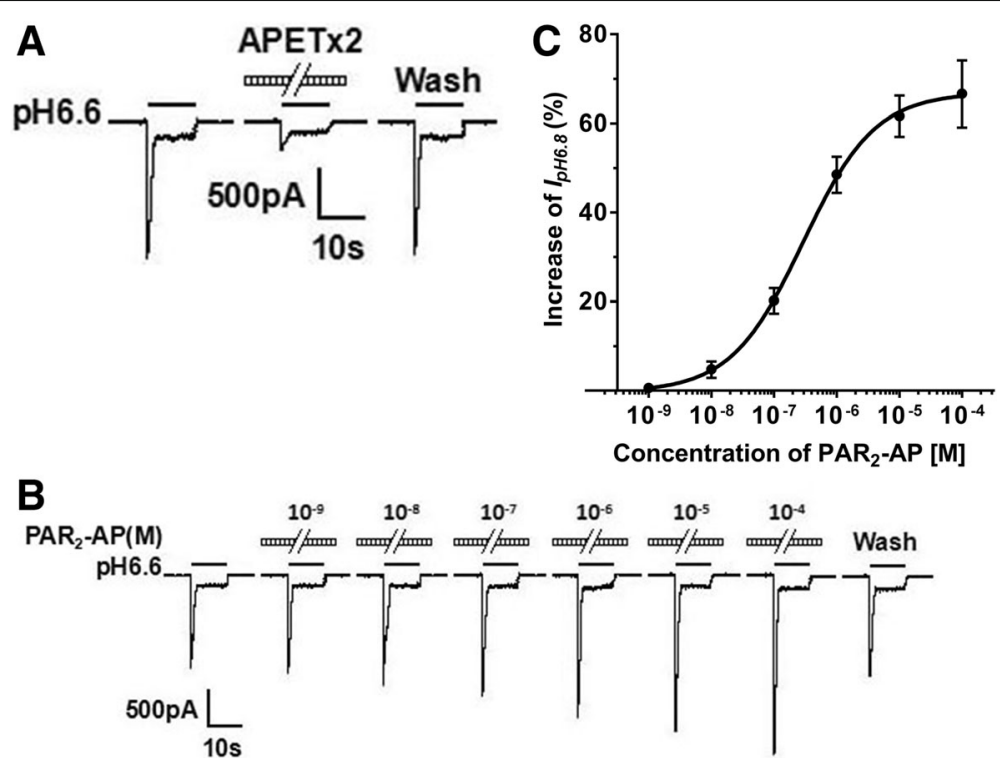

Fig. 1 Potentiation of proton-gated currents by PAR 2 -AP in $C H O$ cells co-expressing ASIC3 and PAR 2 . a Representative traces show currents evoked by a pH 6.6 acidic solution for $5 \mathrm{~s}$ in $\mathrm{CHO}$ cells co-expressing ASIC3 and PAR 2 . The proton-gated current could be blocked by $500 \mathrm{nM}$ APETx2, an

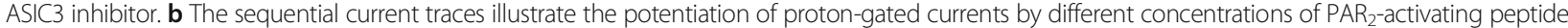
(PAR - AP: 2-furoyl-LIGRLO-NH2, $10^{-9}-10^{-4} \mathrm{M}$ ). Representative currents were recorded for more than $60 \mathrm{~min}$ in a cell with membrane potential clamped at $-60 \mathrm{mV}$. PAR 2 -AP was pre-applied to external solution for $1 \mathrm{~min}$. $\mathbf{c}$ The graph shows $P A R_{2}-A P$ increased the peak amplitude of proton-gated currents in a concentration-dependent manner with an $\mathrm{EC}_{50}$ of $2.9 \times 10^{-7} \mathrm{M}$. Each point represents the mean $\pm \mathrm{SEM}$ of 8 to 10 cells

from $10^{-9}$ to $10^{-4} \mathrm{M}$ in a representative $\mathrm{CHO}$ cell coexpressing ASIC3 and $\mathrm{PAR}_{2}$. The enhancing effect of $\mathrm{PAR}_{2}$-AP was reversible in washout experiments. Figure $1 \mathrm{c}$ shows the concentration-response curve for $\mathrm{PAR}_{2}-\mathrm{AP}$ in the potentiation of ASIC3 currents. PAR - AP had a maximum effect $(66.6 \pm 7.5 \%, n=9)$ at a concentration of 10 ${ }^{-4} \mathrm{M}$. The half-maximal response $\left(\mathrm{EC}_{50}\right)$ value and Hill coefficient of the concentration-response curve for $\mathrm{PAR}_{2}$-AP were $(2.9 \pm 0.2) \times 10^{-7} \mathrm{M}$ and 0.76 , respectively. The results indicated that $\mathrm{PAR}_{2}$-AP enhanced the ASIC3 currents in a concentration-dependent manner.

\section{Activation and steady-state desensitization of ASIC3 expressed in $\mathrm{CHO}$ cells with and without pretreatment of $\mathrm{PAR}_{2}$-AP}

We then investigated whether the potentiation of ASIC3 currents by $\mathrm{PAR}_{2}$-AP was dependent upon pHs. Figure $2 \mathrm{a}$ shows the concentration-response curves to protons in
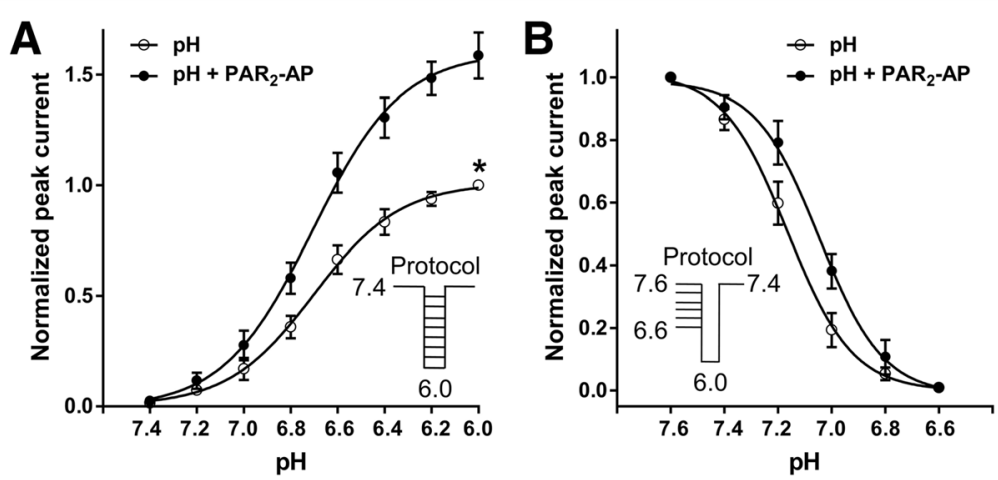

Fig. 2 Concentration-response relationship for protons and steady-state desensitization of ASIC3 with or without the pre-application of PAR2-AP. a The concentration-response curves for protons with or without $10^{-5} \mathrm{M}$ PAR $-A P$ pre-application in $\mathrm{CHO}$ cells co-expressing ASIC3 and PAR 2 . Each point represents the mean \pm SEM of 8 to 10 neurons. All current values were normalized to the current response induced by pH 6.0 applied alone (marked with asterisk). The curves shown are a best fit of the data to the logistic equation $I=I_{\max } /\left[1+\left(\mathrm{pH}_{50} / \mathrm{pH}\right)^{n}\right]$, where $\mathrm{pH}$ is the pH value used, $/$ is the normalized current response value, $\mathrm{pH}_{50}$ is the $\mathrm{pH}$ value for half-maximal current response, and $n$ is the Hill coefficient. The curves for protons without and with $\mathrm{PAR}_{2}{ }^{-}$ AP pre-application were drawn according to the equation described above. $\mathbf{b}$ Steady-state desensitization of homomeric ASIC3 expressed in CHO cells with or without PAR 2 -AP pre-application. PAR $-A P\left(10^{-5} \mathrm{M}\right)$ induced a rightward shift of the $\mathrm{pH}$ dependence of steady-state desensitization. Each point represents the mean \pm SEM of 6 to 8 neurons. The holding $\mathrm{pH}$ varied from 7.6 to 6.6. All currents were induced by pH 6.0 applied alone 
the presence and absence of $\mathrm{PAR}_{2}-\mathrm{AP}\left(10^{-5} \mathrm{M}\right)$. First, after pretreatment of $\mathrm{PAR}_{2}$-AP, the proton concentrationresponse relationship was not changed, but that, the maximal response increased, as indicated by an increase of $58.7 \pm 3.8 \%$ in the maximal current response to protons when $\mathrm{PAR}_{2}-\mathrm{AP}$ was pre-applied. However, the slopes or Hill coefficients of those two curves were essentially similar $\left(n=2.36 \pm 0.13\right.$ in the absence of $\mathrm{PAR}_{2}-\mathrm{AP}$ versus $n=2.28$ \pm 0.15 in the presence of $\mathrm{PAR}_{2}-\mathrm{AP} ; P>0.1$, Bonferroni's post hoc test). Second, the $\mathrm{pH}$ values for half-maximal current response $\left(\mathrm{pH}_{50}\right)$ of both curves had no statistical difference $\left(\mathrm{pH}_{50}\right.$ of $6.70 \pm 0.02$ without $\mathrm{PAR}_{2}$-AP pretreatment versus $\mathrm{pH}_{50}$ of $6.71 \pm 0.04$ with $\mathrm{PAR}_{2}$-AP pretreatment; $P>0.1$, Bonferroni's post hoc test). Third, the threshold $\mathrm{pH}$ values of both curves had no significant difference in the presence and absence of $\mathrm{PAR}_{2}$-AP.

Next, we compared the desensitization properties of ASIC3 currents in the absence or presence of $\mathrm{PAR}_{2}$-AP. Steady-state desensitization was examined by superfusion of $\mathrm{CHO}$ cells co-expressing ASIC3 and $\mathrm{PAR}_{2}$ for $2 \mathrm{~min}$ in solutions with $\mathrm{pH}$ values ranging from 7.6 to 6.6 before application of the $\mathrm{pH} 6.0$ solution. $\mathrm{PAR}_{2}$-AP $\left(10^{-5} \mathrm{M}\right)$ induced a rightward shift of the $\mathrm{pH}$ dependence of steadystate desensitization. The $\mathrm{pH}_{50}$ value for steady-state desensitization changed from $7.16 \pm 0.01$ to $7.05 \pm 0.02$ with the presence of $10^{-5} \mathrm{M} \mathrm{PAR}_{2}$-AP $(P<0.05$, Bonferroni's post hoc test; Fig. $2 b$ ), indicative of a decreased apparent proton affinity under steady-state conditions. The Hill coefficients were $3.58 \pm 0.29$ without $\mathrm{PAR}_{2}$-AP and $3.65 \pm 0.35$ with $\mathrm{PAR}_{2}$-AP.

\section{The receptor and intracellular signal transduction mechanisms underlying potentiation of ASIC3 currents by $\mathrm{PAR}_{2}$-AP}

To verify whether the $\mathrm{PAR}_{2}$-AP potentiation of ASIC3 currents was mediated by $\mathrm{PAR}_{2}$, we co-applied $\mathrm{PAR}_{2}-\mathrm{AP}$ with FSLLRY-NH2, a selective $\mathrm{PAR}_{2}$ antagonist. The peak amplitude of $I_{\mathrm{pH}} 6.6$ increased $61.6 \pm 4.6 \%$ after pretreatment with $\mathrm{PAR}_{2}$ - $\mathrm{AP}\left(10^{-5} \mathrm{M}\right)$ alone for $1 \mathrm{~min}$ in ten $\mathrm{CHO}$ cells co-expressing ASIC3 and $\mathrm{PAR}_{2}$ (Fig. 3a, b). In contrast, $\mathrm{PAR}_{2}$ - AP produced an increase of $7.3 \pm 7.1 \%$ on ASIC3 currents in ten cells pretreated with $10^{-5} \mathrm{M}$ FSLLRY-NH2. And the peak amplitude of $I_{\mathrm{pH}} 6.6$ changed within $5 \%$ after pretreatment with $10^{-5} \mathrm{M}$ FSLLRY-NH2 alone. Thus, the potentiation of $I_{\mathrm{pH}} 6.6$ by pretreatment with $\mathrm{PAR}_{2}$-AP could be blocked by the addition of FSLLRY-NH2 (one-way analysis of variance followed by post hoc Bonferroni's test, $P<0.01, n=10$; Fig. $3 \mathrm{a}$, b). As a possible physiological ligand of the $\mathrm{PAR}_{2}$, trypsin can cleave $\mathrm{PAR}_{2}$ within the extracellular $\mathrm{N}$-terminal domains and then activate the cleaved receptor [3]. Similar to $\mathrm{PAR}_{2}$-AP, pretreatment of $10^{-5} \mathrm{M}$ trypsin for $1 \mathrm{~min}$ also caused an increase of $48.7 \pm 8.3 \%$ on ASIC3 currents in ten $\mathrm{CHO}$ cells co-expressing ASIC3 and $\mathrm{PAR}_{2}$ (Fig. 3a, b).
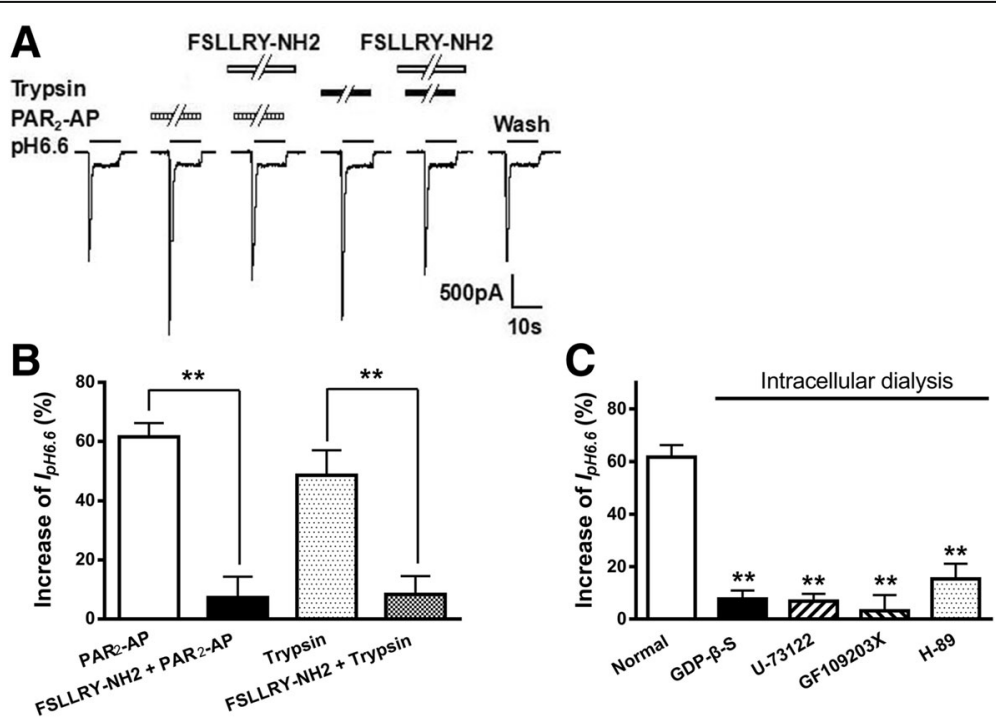

Fig. 3 The receptor and intracellular mechanisms underlying the potentiation of ASIC3 currents by the activation of PAR . The $\mathbf{a}$ current traces and $\mathbf{b}$ bar graphs show that $I_{\mathrm{pH}} 6.6$ was enhanced by PAR $-\mathrm{AP}\left(10^{-5} \mathrm{M}\right)$ pre-applied alone for $1 \mathrm{~min}$ in $\mathrm{CHO}$ cells co-expressing ASIC3 and PAR . This enhancing effect was inhibited by the co-application of PAR $-A P$ and FSLLRY-NH2 $\left(10^{-5} \mathrm{M}\right)$, a selective PAR 2 antagonist. Trypsin, another $\mathrm{PAR}_{2}$ agonist, has a similar increasing effect on $I_{\mathrm{pH}} 6.6$ at concentration of $10^{-5} \mathrm{M}$ for $1 \mathrm{~min}$. And the enhancing effect of trypsin was also inhibited by FSLLRY-NH2 $\left(10^{-5} \mathrm{M}\right)$. Statistical tests were performed using Bonferroni's post hoc test, and significance is shown as follows: ${ }^{*} P<0.01$, compared with white column. $n=10$ in each column. The $\mathbf{c}$ bar graph shows the percentage increases in the $I_{\mathrm{pH}} 6.6$ induced by $\mathrm{PAR} \mathrm{R}_{2}-\mathrm{AP}\left(10^{-5} \mathrm{M}\right)$ with recording pipettes filled with the normal internal solution, non-hydrolyzable GDP analog GDP- $\beta-S(500 \mu \mathrm{M})$, PLC inhibitor U-73122 (10 $\mu \mathrm{M})$, PKC inhibitor GF109203X (2 $\mu \mathrm{M})$, or H-89 $(10 \mu \mathrm{M})$ containing internal solution. Intracellular dialysis of GDP- $\beta-S$, U-73122, GF109203X, or H-89 abolished the enhancing effect of PAR - AP on $I_{\mathrm{pH} \text { 6.6. }}{ }^{* *} P<0.01$, post hoc Bonferroni's test, compared with normal internal solution. $n=10$ in each column 
The enhancing effect of trypsin was also inhibited by FSLLRY-NH2. And trypsin produced an increase of $8.4 \pm$ $6.2 \%$ on ASIC3 currents in ten cells pretreated with 10 ${ }^{-5}$ M FSLLRY-NH2 (Fig. 3a, b).

We further explored the signaling pathway in the downstream of $\mathrm{PAR}_{2}$ for sensitization of ASIC3. We recently reported that $G_{q / 11}$-coupled metabotropic receptor activation such as glutamate (mGluRs), ATP (P2Y), and serotonin $\left(5-\mathrm{HT}_{2}\right)$ receptors causes potentiation of ASICs in a PKC-dependent manner in rat DRG neurons [34-36]. Therefore, we examined whether a similar signal transduction pathway is involved in the modulation of ASIC3 by the activation of PAR 2 , a member of the $G_{q / 11^{-}}$ coupled metabotropic receptor family. GDP- $\beta-S$ (a nonhydrolyzable GDP analog, $500 \mu \mathrm{M}$ ), U-73122 (a PLC inhibitor, $10 \mu \mathrm{M}$ ), or GF109203X (a selective PKC inhibitor, $2 \mu \mathrm{M}$ ) was applied internally to $\mathrm{CHO}$ cells through recording patch pipettes. As shown in Fig. 3c, preapplication of $\mathrm{PAR}_{2}$-AP $\left(10^{-5} \mathrm{M}\right.$ for $\left.1 \mathrm{~min}\right)$ increased $I_{\mathrm{pH}} 6.6$ to $7.7 \pm 3.2,6.9 \pm 2.8$, and $3.2 \pm 6.0 \%$, separately, when GDP- $\beta-S$, U-73122, or GF109203X was included in the pipette solution. They almost completely inhibited the $\mathrm{PAR}_{2}$-AP potentiation of $I_{\mathrm{pH}}$ 6.6, compared with an increase of $61.6 \pm 4.6 \%$ induced by $\mathrm{PAR}_{2}-\mathrm{AP}$ on $I_{\mathrm{pH}} 6.6$ in normal extracellular solution condition $(P<0.01$, post hoc Bonferroni's test, compared with normal internal solution, $n=10$; Fig. 3c). Although $\mathrm{PAR}_{2}$ couples to phospholipase $\mathrm{C}$, leading to stimulation of PKC, PAR2 agonists also increased cAMP generation in DRG neurons and HEK 293 cells, which would activate PKA [37]. H-89, a selective PKA inhibitor, was also applied internally to $\mathrm{CHO}$ cells through recording patch pipettes. Pre-application of
$\mathrm{PAR}_{2}$-AP $\left(10^{-5} \mathrm{M}\right.$ for $\left.1 \mathrm{~min}\right)$ increased $I_{\mathrm{pH}} 6.6$ to $15.3 \pm$ $5.8 \%$ with treatment of $10 \mu \mathrm{M} \mathrm{H}-89$ (Fig. 3c). These data collectively indicated that the potentiation of ASIC3 currents by $\mathrm{PAR}_{2}$-AP was dependent upon GPCR, PLC, PKC, and PKA signaling pathways.

We tested whether $\mathrm{PAR}_{2}-\mathrm{AP}$ could enhance acidevoked currents mediated by heteromeric channels containing ASIC3. ASIC3-containing heteromeric channels were expressed with $\mathrm{PAR}_{2}$ in $\mathrm{CHO}$ cells. To minimize the formation of ASIC3 homomers, ASIC3 and another ASIC subunit were co-expressed at the 1:3 ratio in $\mathrm{CHO}$ cells. After pretreatment of $\mathrm{PAR}_{2}$-AP $\left(10^{-5} \mathrm{M}\right)$ for $1 \mathrm{~min}$, the peak currents of heteromeric ASIC1a+3, ASIC1b+3, and ASIC $2 \mathrm{~b}+3$ channels increased $51.6 \pm 6.5 \%, 55.2 \pm 5.9 \%$, and $68.1 \pm 7.3 \%$, respectively ( $n=8$; Fig. 4 a, b). These results show that $\mathrm{PAR}_{2}-\mathrm{AP}$ also enhanced currents induced by the heteromeric ASIC3 channels. We also examined the effects of $\mathrm{PAR}_{2}-\mathrm{AP}$ and trypsin on ASIC3 currents in $\mathrm{CHO}$ cells expressing alone ASIC3, but not expressing $\mathrm{PAR}_{2}$. Neither PAR $\mathrm{P}_{2}$-AP nor trypsin had an effect on $I_{\mathrm{pH}} 6.6$ at a concentration of $10^{-5} \mathrm{M}$ in ASIC3-transfected $\mathrm{CHO}$ cells (one-way analysis of variance followed by post hoc Bonferroni's test, $P>0.1, n=10$; Fig. 4c, d).

\section{Potentiation of proton-evoked currents and spikes by the activation of $\mathrm{PAR}_{2}$ in rat DRG neurons}

ASICs expressed in primary sensory neurons respond to local acidosis with membrane depolarization and spikes, which is thought to be the initial trigger for pain sensation [21]. $\mathrm{PAR}_{2}$ is also expressed in primary sensory neurons and activated by endogenous proteases $[7,8]$. To gain insights into the pathophysiological function of interaction
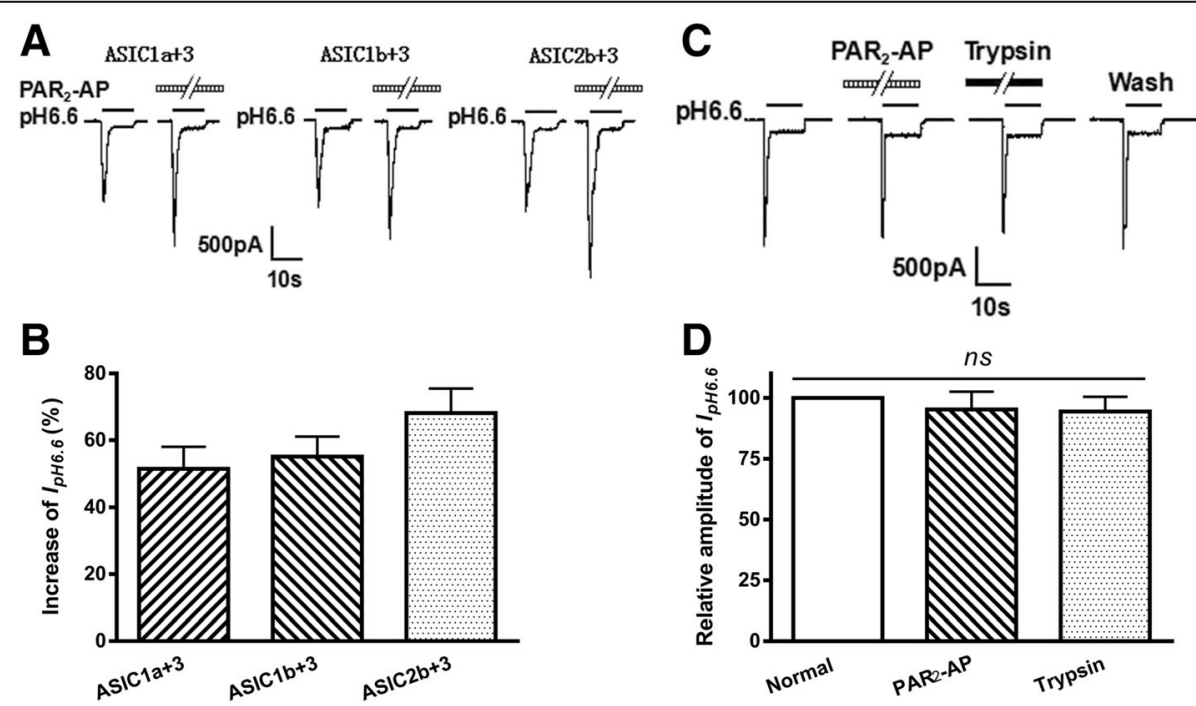

Fig. $4 \mathrm{PAR}_{2}$-AP potentiation of proton-gated currents mediated by heteromeric ASIC3 channels. Representative $\mathbf{a}$ current traces and $\mathbf{b}$ bar graphs show that $/ \mathrm{pH} 6.6$ was also enhanced by PAR 2 -AP $\left(10^{-5} \mathrm{M}\right)$ pre-applied for $1 \mathrm{~min}$ in $\mathrm{CHO}$ cells co-expressing PAR and heteromeric ASIC3 plus $1 \mathrm{a}$, $1 \mathrm{~b}, 2 \mathrm{a}$, or $2 \mathrm{~b}$ channels. $n=8$ in each column. The c current traces and $\mathbf{d}$ bar graphs show that PAR 2 -AP and trypsin had no effect on $/ \mathrm{pH} 6.6$ in $\mathrm{CHO}$ cells expressing alone homomeric ASIC3, but not expressing PAR . Currents were normalized to control (100\%, white column). $n=10$ in each column 
between ASIC3 and $\mathrm{PAR}_{2}$, we next observed whether $\mathrm{PAR}_{2}$ activation would also sensitize ASIC3 in acutely isolated rat DRG neurons by patch clamp recording. All proton-gated currents were recorded in the presence of capsazepine $(10 \mu \mathrm{M})$ to block the proton-induced TRPV1 activation [38]. A rapid reduction of extracellular $\mathrm{pH}$ from 7.4 to 6.6 for $5 \mathrm{~s}$ evoked an inward current $\left(I_{\mathrm{pH}} 6.6\right)$ in most native DRG neurons (72.0\%, 36/50, from 12 rats). The acidosis-evoked currents were characterized by a large transient peak current followed by fast inactivation and then a small sustained current with no or very slow inactivation. In rat DRG neurons, ASIC3 is mainly present in heterotrimeric channels, which require higher APETx2 concentrations for inhibition [39]. We found that the ASIC currents are also blocked by $2 \mu \mathrm{M}$ of APETx 2 in eight DRG neurons tested (Fig. 5a). Thus, they may be ASIC3-like currents and were mainly observed in the next study. Similar to that observed in $\mathrm{CHO}$ cells co-expressing ASIC3 and $\mathrm{PAR}_{2}$, the proton-evoked currents were enhanced by the pre-application of $\mathrm{PAR}_{2}-\mathrm{AP}$ in some DRG neurons sensitive to acidic stimuli (Fig. 5a, b). The peak amplitude of $I_{\mathrm{pH}} 6.6$ increased $57.1 \pm 9.8 \%$ after pretreatment with $\mathrm{PAR}_{2}$-AP $\left(10^{-5} \mathrm{M}\right)$ for $1 \mathrm{~min}$ in nine DRG neurons tested (Fig. 5b). However, the peak amplitude of $I_{\mathrm{pH}} 6.6$ only increased $9.3 \pm 44 \%$ when $\mathrm{PAR}_{2}$-AP $\left(10^{-5} \mathrm{M}\right)$ was co-treated with $10^{-5}$ M FSLLRY-NH2 $(P<0.01$, compared with $\mathrm{PAR}_{2}$-AP alone column, one-way ANOVA followed by post hoc Bonferroni's test, $n=9$ ), suggesting that potentiation of ASIC currents by $\mathrm{PAR}_{2}-\mathrm{AP}$ was blocked by the addition of FSLLRY-NH2, a selective PAR 2 antagonist, in rat DRG neurons (Fig. 5a, b). Like $\mathrm{PAR}_{2}$-AP, trypsin $\left(10^{-5} \mathrm{M}\right)$ pre-application to the DRG neurons for 1 min also produced an increase of $48.7 \pm 8.3 \%$ on $I_{\mathrm{pH}} 6.6$ (Fig. 5a, b). And the potentiation of ASIC currents by trypsin was also inhibited by $10^{-5} \mathrm{M}$ FSLLRY-NH2 in rat DRG neurons (Fig. 5a, b).

To investigate whether the $\mathrm{PAR}_{2}$-AP enhancement of ASIC3 relates to increase neuronal excitability, we recorded action potentials (APs or spikes) in DRG neurons in current clamp mode in the presence of capsazepine $(10 \mu \mathrm{M})$ to block proton-induced TRPV1 activation [38]. As shown in Fig. 5c, a pH drop from 7.4 to 6.6 for 5 s could trigger bursts of APs in a DRG neuron tested. Consistent with the results that $\mathrm{PAR}_{2}$-AP potentiated proton-gated currents under voltage clamp conditions, pretreatment of $10^{-5} \mathrm{M} \mathrm{PAR}_{2}$-AP for $1 \mathrm{~min}$ also increased acidosis-evoked spikes. In the nine DRG neurons tested from six rats, pretreatment of $\mathrm{PAR}_{2}-\mathrm{AP}$ increased the mean number of spikes induced by acidosis from $3.5 \pm 0.6$ of control condition to $6.3 \pm 0.9(P<0.05$, paired $t$ test, $n=9) \quad$ (Fig. $5 \mathrm{~d})$.
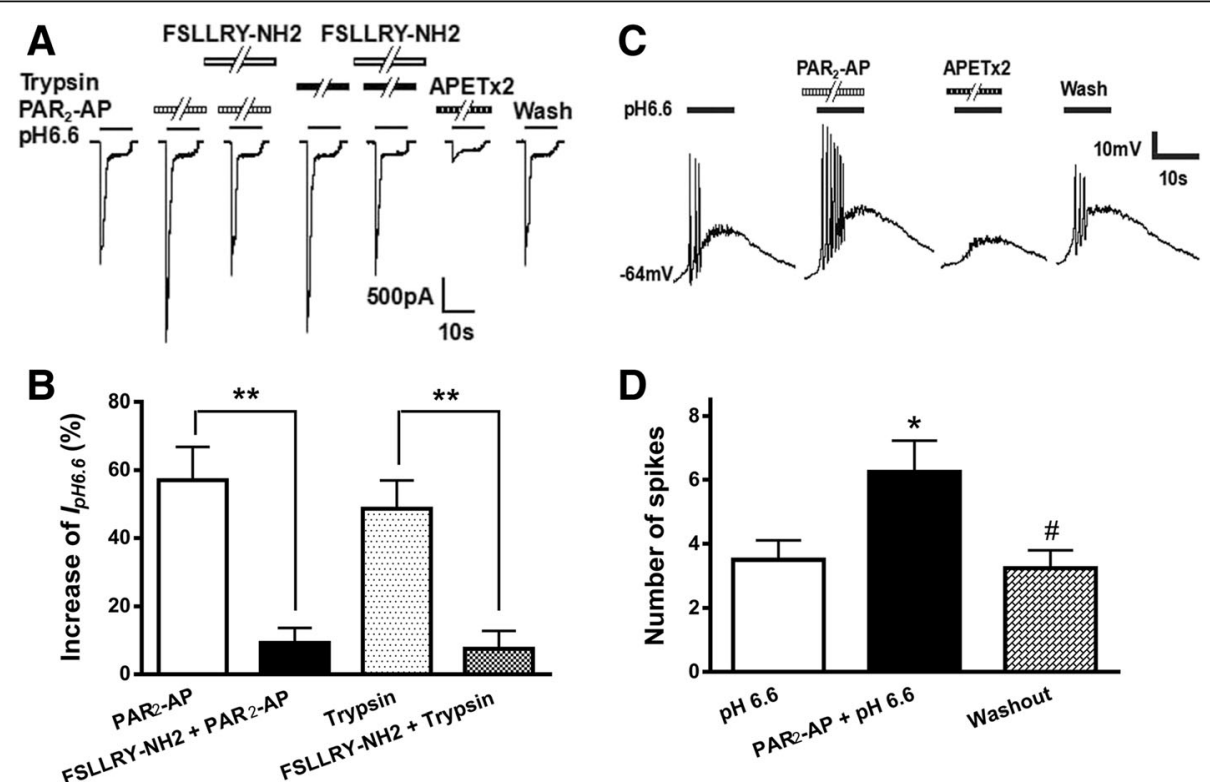

Fig. 5 Potentiation of proton-evoked currents and spikes by the activation of PAR in rat DRG neurons. The $\mathbf{a}$ current traces and $\mathbf{b}$ bar graphs show that $I_{\mathrm{pH}} 6.6$ was enhanced by PAR $-\mathrm{AP}\left(10^{-5} \mathrm{M}\right)$ or trypsin $\left(10^{-5} \mathrm{M}\right)$ pre-applied alone for $1 \mathrm{~min}$ in rat DRG neurons. This enhancing effect of $P A R_{2}-A P$ was inhibited by FSLLRY-NH2 $\left(10^{-5} \mathrm{M}\right)$, a selective PAR 2 antagonist. Also, this proton-induced current could be completely blocked by $2 \mu \mathrm{M}$ APETx2, an ASIC3 inhibitor. Currents were evoked by extracellular application of a pH 6.6 solution for $5 \mathrm{~s}$ in the presence of capsazepine $(10 \mu \mathrm{M})$ to block proton-induced TRPV1 activation. DRG neurons with membrane potential clamped at $-60 \mathrm{mV}$. The $\mathbf{c}$ spike recordings and $\mathbf{d}$ bar graphs show that pretreatment of PAR $-A P\left(10^{-5} \mathrm{M}\right.$, for $\left.1 \mathrm{~min}\right)$ increased the acidosis-induced number of action potentials in DRG neurons. The spikes were not evoked by pH 6.6 acidic solution in the presence of $2 \mu \mathrm{M}$ APETx2. Action potentials were evoked by pH 6.6 acidic solution for $5 \mathrm{~s}$ with current clamp recording in the presence of capsazepine $(10 \mu \mathrm{M})$ to block proton-induced TRPV1 activation. The acidosis-evoked action potentials recovered to control condition after washout of $\mathrm{PAR}_{2}-\mathrm{AP}$. ${ }^{*} P<0.05$, paired $t$ test, compared with $\mathrm{pH} 6.6$ column alone; \#P<0.05, paired $t$ test, compared with $\mathrm{PAR}_{2}-\mathrm{AP}+\mathrm{pH} 6.6$ column, $n=9$ in each column 
After a washout of $\mathrm{PAR}_{2}-\mathrm{AP}$, the acidosis-evoked spikes recovered to the control condition. In addition, the acidosis-evoked spikes were completely blocked by $2 \mu \mathrm{M}$ of APETx2, suggesting that ASIC3-containing channels mediated the spikes (Fig. 5c). These results indicated that the activation of $\mathrm{PAR}_{2}$ reversibly increased proton-induced membrane excitability of rat DRG neurons.

\section{Exacerbation of acidosis-induced ASIC3-dependent noci- fensive behaviors by $P A R_{2}-A P$ in rats}

The above results demonstrated that ASIC3 activity was potentiated by $\mathrm{PAR}_{2}$ activation in vitro. We finally ascertain whether $\mathrm{PAR}_{2}$-AP facilitates pain-related behaviors through interacting with ASIC3 in vivo. Acetic acid (0.6\%) was injected into the right hind paws of rats and measured the number of flinches that the animals spent licking and/ or lifting the injected paw. Intraplantar injection of acetic acid elicits an intense flinch/shaking response which mainly occurred during 0-5 min after injection of acetic acid $[21,32]$. We found that pre-administration of $\mathrm{PAR}_{2}$ AP dose-dependently exacerbated the acidosis-induced nocifensive behaviors (Fig. 6a). The acetic acid-induced number of flinches was significantly greater in rats pretreated with medium and high dose (3 and $10 \mu \mathrm{g})$ of $\mathrm{PAR}_{2}$-AP than that observed in rats injected with acetic acid alone (Bonferroni's post hoc test, $P<0.05$ and $P<$ $0.01, n=10)$. However, the low dose $(1 \mu \mathrm{g})$ of $\mathrm{PAR}_{2}$-AP had no effect on the acidosis-induced nocifensive behaviors (Bonferroni's post hoc test, $P>0.1, n=10$ ). In addition, the exacerbating effect of $10 \mu \mathrm{g} \mathrm{PAR}_{2}$-AP on acidosis-induced nocifensive behaviors was blocked by coadministration of $20 \mu \mathrm{g}$ FSLLRY-NH2, a selective $\mathrm{PAR}_{2}$ antagonist (Bonferroni's post hoc test, $P<0.01$, compared with $10 \mu \mathrm{g} \mathrm{PAR}_{2}$-AP alone, $n=10$; Fig. 6a). These results indicated that periphery activation of $\mathrm{PAR}_{2}$ by $\mathrm{PAR}_{2}-\mathrm{AP}$ contributed to acidosis-induced nocifensive behaviors in rats. Acetic acid-induced nociceptive response in rats was potently blocked by treatment with APETx2 $(20 \mu \mathrm{M}$, $20 \mu \mathrm{l}$ ), an ASIC3 blocker, demonstrating the involvement of ASIC3 in the acidosis-induced nociception (Fig. 6b). In addition, the increased ASIC3-mediated pain behavior induced by $10 \mu \mathrm{g} \mathrm{PAR}_{2}$-AP can also be potently inhibited by treatment with APETx2 (20 $\mu \mathrm{M}, 20 \mu \mathrm{l}$; Fig. 6b).

\section{Discussion}

We found that there was a functional interaction between $\mathrm{PAR}_{2}$ and ASIC3 in transfected cell lines, DRG neurons, and intact animals. The present study provided electrophysiological and behavioral evidences that activation of $\mathrm{PAR}_{2}$ can sensitize ASIC3.

In $\mathrm{CHO}$ cells expressing ASIC3 and $\mathrm{PAR}_{2}$ and rat DRG neurons, a rapid drop in the extracellular $\mathrm{pH}$ from 7.4 to 6.6 evoked an inward current that can be characterized by a large transient current followed by fast inactivation and

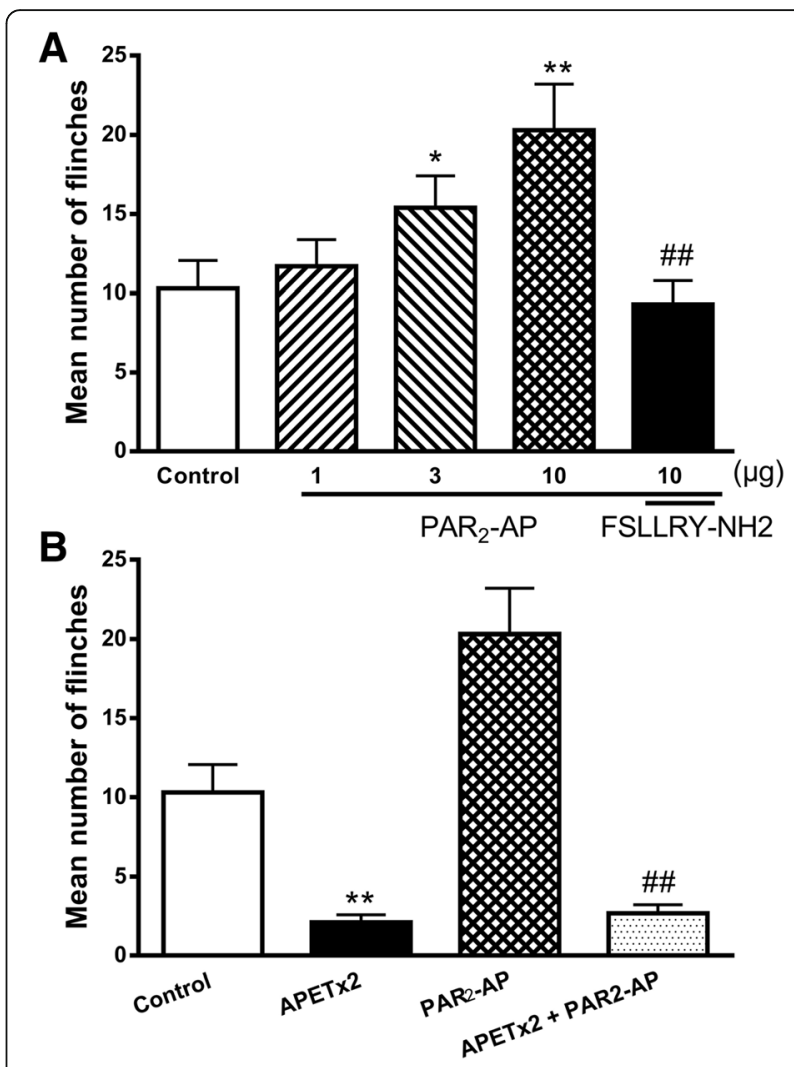

Fig. 6 Effect of $P A R_{2}-A P$ on nociceptive responses to intraplantar injection of acetic acid in rats. The a bar graph shows that the nociceptive responses are evoked by intraplantar injection of acetic acid (30 $\mu \mathrm{l}, \mathrm{pH} 6.0$ ) in the presence of the TRPV1 inhibitor capsazepine $(100 \mu \mathrm{M})$. The pretreatment of $\mathrm{PAR}_{2}-\mathrm{AP}$ increased the flinching behavior induced by acetic acid in a dose-dependent manner (1-10 $\mu \mathrm{g})$. The effect of PAR 2 -AP $(10 \mu \mathrm{g})$ was blocked by co-treatment of FSLLRY-NH2 $(20 \mu \mathrm{g})$, a selective $P A R_{2}$ antagonist. ${ }^{*} P<0.05,{ }^{* *} P<0.01$, Bonferroni's post hoc test, compared with control; \#\#P<0.01, Bonferroni's post hoc test, compared with $\mathrm{PAR}_{2}-\mathrm{AP}(10 \mu \mathrm{g})$ column. The $\mathbf{b}$ bar graph shows that the acidosis-evoked nociception and increased pain response induced by PAR $-A P(10 \mu \mathrm{g})$ were blocked by pretreatment with APETx2 $(20 \mu \mathrm{l}, 20 \mu \mathrm{M})$, an ASIC3 inhibitor. ${ }^{* *} P<0.01$, Bonferroni's post hoc test, compared with control; \#\#P<0.01, Bonferroni's post hoc test, compared with $P A R_{2}-A P$ column. Each bar represents the number of flinches that the animals spent licking/lifting the injected paw during first 5-min observation period (mean \pm SEM of 10 rats in each group)

then a small sustained current with no or very slow inactivation [33]. These acidosis currents were mediated by ASIC3-containing homomeric and heteromeric channels, since peak currents could be blocked by APETx2, an ASIC3 blocker, although it also inhibits voltage-gated $\mathrm{Na}^{+}$ channels at higher concentration [40]. In peripheral sensory neurons, ASIC3 is detected in axons, axon terminals, and cell bodies, where its activation contributes to pain signaling [20-22]. ASIC3 has emerged as critical pH sensors predominantly expressed in nociceptors [22]. We found that activation of $\mathrm{PAR}_{2}$ by $\mathrm{PAR}_{2}$-AP produced an enhancing effect on ASIC3 currents in $\mathrm{CHO}$ cells transfected 
with homomeric and heteromeric ASIC3 and $\mathrm{PAR}_{2}$. $\mathrm{PAR}_{2-}$ $\mathrm{AP}$ sensitized ASIC3 by increasing the maximum response without changing the $\mathrm{EC}_{50}$ values. Trypsin, a possible physiological ligand of the $\mathrm{PAR}_{2}$, had a similar potentiating effect on ASIC3 currents. $\mathrm{PAR}_{2}-\mathrm{AP}$ and trypsin increased ASIC3 and ASIC3-like currents through $\mathrm{PAR}_{2}$, since their effects were blocked by FSLLRY-NH2, a selective $\mathrm{PAR}_{2}$ antagonist, in transfected $\mathrm{CHO}$ cells and DRG neurons. However, neither $\mathrm{PAR}_{2}-\mathrm{AP}$ nor trypsin had an effect on ASIC3 currents in $\mathrm{CHO}$ cells expressing alone ASIC3, but not expressing $\mathrm{PAR}_{2}$. These results indicated that a functional interaction occurred between $\mathrm{PAR}_{2}$ and ASIC3.

The current study showed that $\mathrm{PAR}_{2}$-AP potentiation of ASIC3 currents was blocked by intracellular dialysis of GDP- $\beta-S$, indicating that $G$ proteins were involved in the intracellular mechanisms of this potentiation. $\mathrm{PAR}_{2}$ primarily couple the $G_{q / 11}$ subtype of $G$ protein family, which activates PLC [1]. Lack of the potentiating effect in cells treated with PLC inhibitor U-73122 indicated a PLC-dependent pathway is predominantly involved in functional interaction between $\mathrm{PAR}_{2}$ and ASIC3. One of the consequences of PLC activation is the breakdown of PIP2 into DAG and inositol triphosphate, followed by mobilization of calcium and activation of PKC. Our observation that PKC inhibitor GF109203X also prevented the potentiation of ASIC3 currents by $\mathrm{PAR}_{2}$-AP indicated that activation of $\mathrm{PKC}$ played a major role in $\mathrm{PAR}_{2}$-induced sensitization of ASIC3. Similarly, electrophysiological studies have suggested that $\mathrm{PAR}_{2}$ sensitizes TRPV1, TRPV4, and TRPA1, which was blocked by a PLC inhibitor [14, 16, 18]. It has been shown that ASIC3 is modulated by proinflammatory mediators such as serotonin and bradykinin via a PKC pathway [41-43]. We recently reported that $G_{q / 11}$-coupled metabotropic receptor activation such as glutamate (mGluRs), ATP (P2Y), and serotonin $\left(5-\mathrm{HT}_{2}\right)$ receptors causes potentiation of ASICs in a PKC-dependent manner in rat DRG neurons [34-36]. $\mathrm{PAR}_{2}$ has been found to sensitize TRPV1, TRPV4, and P2X3 ATP receptor in a PKC- and PKA-dependent manner [16, 37, 44]. Our observation that inhibition of PKA with $\mathrm{H}-89$ reduced the potentiation of ASIC3 currents by $\mathrm{PAR}_{2}$-AP indicated that PKA also mediated PAR2-induced sensitization of ASIC3. It has been shown that heteromeric ASIC3/ASIC2b channels, but not homomeric ASIC3 channels, are regulated by PKC and this regulation requires PICK1 [42]. The present study showed that PAR2-induced sensitization of homomeric ASIC3 channels required simultaneous activation of PKC and PKA, since blocking either of the these kinases prevented the potentiation of ASIC3 currents by $\mathrm{PAR}_{2}$-AP. It remains to be determined whether these kinases act sequentially or in parallel.

The present study showed that $\mathrm{PAR}_{2}$-AP potentiated acidosis-evoked currents and membrane excitability in dissociated rat DRG neurons, indicating that $\mathrm{PAR}_{2}$ activation also sensitized ASIC3 in rat sensory neurons. In consistent with our previous report [34-36], a rapid reduction of extracellular $\mathrm{pH}$ evoked an ASIC3 current in most native DRG neurons, since the proton-evoked currents were blocked by APETx2. Similar to that observed in $\mathrm{CHO}$ cells co-expressing ASIC3 and $\mathrm{PAR}_{2}$, pre-application of $\mathrm{PAR}_{2}$-AP or trypsin also enhanced the proton-evoked currents through $\mathrm{PAR}_{2}$ in some DRG neurons sensitive to acidic stimuli. Recently, it has been reported that the activation of $\mathrm{PAR}_{2}$ enhances weak acid-induced ATP release through the sensitization of TRPV1 and ASIC3 in human esophageal epithelial cells [45]. Extracellular acidic stimuli open ASICs and mainly induce sodium influx, which can depolarize membrane potentials to the threshold of excitability and result in bursts of action potentials. The current study showed that acidosis-evoked action potentials were enhanced by $\mathrm{PAR}_{2}$-AP. The increased acidosis-evoked neuronal excitability appeared to correlate with $\mathrm{PAR}_{2}$-AP potentiation of ASIC3 currents in voltage clamp experiments. Moreover, pain sensation that was caused through the ASIC3 was also potentiated by the $\mathrm{PAR}_{2}$ activation. In the behavior studies, we found that intraplantar pretreatment of $\mathrm{PAR}_{2}$-AP dose-dependently exacerbated the acidosisinduced nocifensive behaviors in rats. The combined data indicated that $\mathrm{PAR}_{2}$ activation indeed increased ASIC3 activity, not only at the cellular level but also at the behavioral level.

ASIC3 is expressed in both DRG cell bodies and sensory terminals, which monitors extracellular $\mathrm{pH}$ fall and contributes to proton-evoked pain signaling [20, 21]. It has been shown that ASIC3 plays an important role in various pain conditions such as inflammatory pain, postoperative pain, and migraine $[22,29,31] . \mathrm{PAR}_{2}$ is also expressed on a subset of primary sensory neurons and functionally involved in peripheral mechanisms of inflammation and pain $[7,8]$. Activation of $\mathrm{PAR}_{2}$ on sensory nerve ending evokes thermal and mechanical hyperalgesia [9]. Our observation that $\mathrm{PAR}_{2}$ activation sensitized ASIC3 is likely to be of physiological relevance in pathological condition. For example, ASIC3 plays an important role in postoperative pain, while PAR2 activation by mast cell tryptase is involved in postoperative pain $[12,29]$. Protons are released from damaged cells and the de-granulation of mast cells during tissue injury and inflammation, and extracellular $\mathrm{pH}$ values can drop to $5.4[25,26,46]$. Trypsin and tryptase, the selective agonists on physiological state for $\mathrm{PAR}_{2}$, could be released from different cell types including mast cells in peripheral tissue and visceral organs during tissue injury and inflammation $[2,47,48]$. The endogenous proteases can activate $\mathrm{PAR}_{2}$ expressed in peripheral neuronal terminals. As a GPCR, $\mathrm{PAR}_{2}$ activation itself may be not 
sufficient to induce action potentials in primary afferents [15]. Thus, the underlying mechanism of $\mathrm{PAR}_{2}$-mediated hyperalgesia may involve the interaction between $\mathrm{PAR}_{2}$ and other molecules such as ion channels. During inflammation and injury, it is possible that both proteases and protons release together. The released protons are sufficient to activate ASIC3, subsequently evoke action potentials, and produce pain signaling in primary afferents [26]. Proteases cleave and activate $\mathrm{PAR}_{2}$ in peripheral sensory terminals. $\mathrm{PAR}_{2}$ subsequently activates $\mathrm{G}$ proteins, which result in PKC activation via PLC and PKA. The current study demonstrated that the $\mathrm{PAR}_{2}$ signaling may further sensitize ASIC3 in nociceptors, which exacerbated acidosis-evoked nociception.

\section{Conclusions}

We have revealed a functional interaction between $\mathrm{PAR}_{2}$ and ASIC3. Activation of $\mathrm{PAR}_{2}$ signaling sensitized ASIC3 in a combination of observations in transfected cell lines, DRG, and intact animals. Sensitization of ASIC3 by PAR 2 required activation of PLC, PKC, and PKA, which contributed to acidosis-evoked pain. Our results indicated a novel peripheral mechanism underlying $\mathrm{PAR}_{2}$ involvement in hyperalgesia by sensitizing ASIC3 in primary sensory neurons. Targeting one or more of these signaling molecules may present new opportunities for the treatment of acidosis-mediated pain.

\section{Abbreviations}

ASICs: Acid-sensing ion channels; CHO: Chinese hamster ovary; DRG: Dorsal root ganglion; $\mathrm{EC}_{50}$ : Half-maximal response; GPCRs: G protein-coupled receptors; $I_{\mathrm{pH}}$ : Proton-gated current; $\mathrm{PAR}_{2}-\mathrm{AP}$ : PAR $\mathrm{R}_{2}$-activating peptide; PARs: Proteinase-activated receptors; TRP: Transient receptor potential

\section{Acknowledgements}

Not applicable.

\section{Funding}

This work was supported by the National Natural Science Foundation of China (No. 81671101, No. 31471062) and Natural Science Foundation of Hubei Province of China (No. 2015CFA145).

\section{Availability of data and materials}

Not applicable.

\section{Authors' contributions}

WPH, MJ, and JW conceived and designed the study. JW, TTL, CYQ, YMZ, and PR performed the experiments. JW and MJ analyzed the data. WPH and JW wrote the manuscript. All authors have read and approved the final manuscript.

\section{Ethics approval and consent to participate}

The experimental protocol was approved by the animal research ethics committee of Hubei University of Science and Technology (No. 2016-67).

\section{Consent for publication}

Not applicable.

\section{Competing interests}

The authors declare that they have no competing interests.

\section{Publisher's Note}

Springer Nature remains neutral with regard to jurisdictional claims in published maps and institutional affiliations.

\section{Author details}

${ }^{1}$ Research Center of Basic Medical Sciences, School of Basic Medical Sciences, Hubei University of Science and Technology, 88 Xianning Road, Xianning 437100, Hubei, People's Republic of China. ${ }^{2}$ Department of Physiology, School of Basic Medical Sciences, Hubei University of Science and Technology, 88 Xianning Road, Xianning 437100, Hubei, People's Republic of China. ${ }^{3}$ Department of Pharmacology, Hubei University of Science and Technology, 88 Xianning Road, Xianning 437100, Hubei, People's Republic of China.

Received: 21 February 2017 Accepted: 11 July 2017

Published online: 28 July 2017

\section{References}

1. Hollenberg MD, Compton SJ. International Union of Pharmacology. XXVIII. Proteinase-activated receptors. Pharmacol Rev. 2002:54:203-17.

2. Adams MN, Ramachandran R, Yau MK, Suen JY, Fairlie DP, Hollenberg MD, Hooper JD. Structure, function and pathophysiology of protease activated receptors. Pharmacol Ther. 2011;130:248-82.

3. Gieseler F, Ungefroren $\mathrm{H}$, Settmacher U, Hollenberg MD, Kaufmann R Proteinase-activated receptors (PARs) - focus on receptor-receptorinteractions and their physiological and pathophysiological impact. Cell Commun Signal. 2013;11:86.

4. Hollenberg MD, Renaux B, Hyun E, Houle S, Vergnolle N, Saifeddine M, Ramachandran R. Derivatized 2-furoyl-LIGRLO-amide, a versatile and selective probe for proteinase-activated receptor 2: binding and visualization. J Pharmacol Exp Ther. 2008;326:453-62.

5. Bunnett NW. Protease-activated receptors: how proteases signal to cells to cause inflammation and pain. Semin Thromb Hemost. 2006;32 Suppl 1:39-48.

6. Mrozkova P, Palecek J, Spicarova D. The role of protease-activated receptor type 2 in nociceptive signaling and pain. Physiol Res. 2016;65:357-67.

7. Steinhoff M, Vergnolle N, Young SH, Tognetto M, Amadesi S, Ennes HS, Trevisani M, Hollenberg MD, Wallace JL, Caughey GH, et al. Agonists of proteinase-activated receptor 2 induce inflammation by a neurogenic mechanism. Nat Med. 2000:6:151-8.

8. Hoogerwerf WA, Zou L, Shenoy M, Sun D, Micci MA, Lee-Hellmich H, Xiao $S Y$, Winston JH, Pasricha PJ. The proteinase-activated receptor 2 is involved in nociception. J Neurosci. 2001;21:9036-42.

9. Vergnolle N, Bunnett NW, Sharkey KA, Brussee V, Compton SJ, Grady EF, Cirino G, Gerard N, Basbaum Al, Andrade-Gordon P, et al. Proteinaseactivated receptor-2 and hyperalgesia: a novel pain pathway. Nat Med. 2001;7:821-6.

10. Chen Y, Yang C, Wang ZJ. Proteinase-activated receptor 2 sensitizes transient receptor potential vanilloid 1, transient receptor potential vanilloid 4, and transient receptor potential ankyrin 1 in paclitaxel-induced neuropathic pain. Neurosci. 2011;193:440-51.

11. Lam DK, Dang D, Zhang J, Dolan JC, Schmidt BL. Novel animal models of acute and chronic cancer pain: a pivotal role for PAR2. J Neurosci. 2012;32: 14178-83.

12. Oliveira SM, Silva CR, Ferreira J. Critical role of protease-activated receptor 2 activation by mast cell tryptase in the development of postoperative pain. Anesthesiol. 2013;118:679-90.

13. Tillu DV, Hassler SN, Burgos-Vega CC, Quinn TL, Sorge RE, Dussor G, Boitano S, Vagner J, Price TJ. Protease-activated receptor 2 activation is sufficient to induce the transition to a chronic pain state. Pain. 2015;156:859-67.

14. Amadesi S, Nie J, Vergnolle N, Cottrell GS, Grady EF, Trevisani M, Manni C, Geppetti P, McRoberts JA, Ennes H, et al. Protease-activated receptor 2 sensitizes the capsaicin receptor transient receptor potential vanilloid receptor 1 to induce hyperalgesia. J Neurosci. 2004;24:4300-12.

15. Dai Y, Moriyama T, Higashi T, Togashi K, Kobayashi K, Yamanaka H, Tominaga M, Noguchi K. Proteinase-activated receptor 2-mediated potentiation of transient receptor potential vanilloid subfamily 1 activity reveals a mechanism for proteinase-induced inflammatory pain. J Neurosci. 2004;24:4293-9.

16. Grant AD, Cottrell GS, Amadesi S, Trevisani M, Nicoletti P, Materazzi S, Altier C, Cenac N, Zamponi GW, Bautista-Cruz F, et al. Protease-activated receptor 2 sensitizes the transient receptor potential vanilloid 4 ion channel to cause mechanical hyperalgesia in mice. J Physiol. 2007;578:715-33. 
17. Poole DP, Amadesi S, Veldhuis NA, Abogadie FC, Lieu T, Darby W, Liedtke W, Lew MJ, Mclntyre P, Bunnett NW. Protease-activated receptor 2 (PAR2) protein and transient receptor potential vanilloid 4 (TRPV4) protein coupling is required for sustained inflammatory signaling. J Biol Chem. 2013;288:5790-802.

18. Dai Y, Wang S, Tominaga M, Yamamoto S, Fukuoka T, Higashi T, Kobayashi K, Obata K, Yamanaka H, Noguchi K. Sensitization of TRPA1 by PAR2 contributes to the sensation of inflammatory pain. J Clin Invest. 2007;117:1979-87.

19. Wemmie JA, Price MP, Welsh MJ. Acid-sensing ion channels: advances, questions and therapeutic opportunities. Trends Neurosci. 2006;29:578-86.

20. Price MP, Mcllwrath SL, Xie J, Cheng C, Qiao J, Tarr DE, Sluka KA, Brennan TJ, Lewin GR, Welsh MJ. The DRASIC cation channel contributes to the detection of cutaneous touch and acid stimuli in mice. Neuron. 2001;32:1071-83.

21. Deval E, Noel J, Lay N, Alloui A, Diochot S, Friend V, Jodar M, Lazdunski M, Lingueglia E. ASIC3, a sensor of acidic and primary inflammatory pain. EMBO J. 2008;27:3047-55.

22. Deval $E$, Lingueglia E. Acid-sensing ion channels and nociception in the peripheral and central nervous systems. Neuropharmacology. 2015;94:49-57.

23. Wemmie JA, Taugher RJ, Kreple CJ. Acid-sensing ion channels in pain and disease. Nat Rev Neurosci. 2013;14:461-71.

24. Kellenberger S, Schild L. International Union of Basic and Clinical Pharmacology. $\mathrm{XCl}$. Structure, function, and pharmacology of acid-sensing ion channels and the epithelial $\mathrm{Na}^{+}$channel. Pharmacol Rev. 2015;67:1-35.

25. Basbaum Al, Bautista DM, Scherrer G, Julius D. Cellular and molecular mechanisms of pain. Cell. 2009;139:267-84.

26. Steen $\mathrm{KH}$, Reeh PW, Anton F, Handwerker HO. Protons selectively induce lasting excitation and sensitization to mechanical stimulation of nociceptors in rat skin, in vitro. J Neurosci. 1992;12:86-95.

27. Ikeuchi M, Kolker SJ, Burnes LA, Walder RY, Sluka KA. Role of ASIC3 in the primary and secondary hyperalgesia produced by joint inflammation in mice. Pain. 2008;137:662-9.

28. Noel J, Salinas M, Baron A, Diochot S, Deval E, Lingueglia E. Current perspectives on acid-sensing ion channels: new advances and therapeutic implications. Expert Rev Clin Pharmacol. 2010;3:331-46.

29. Deval E, Noel J, Gasull X, Delaunay A, Alloui A, Friend V, Eschalier A, Lazdunski $M$, Lingueglia E. Acid-sensing ion channels in postoperative pain. J Neurosci. 2011;31:6059-66.

30. Karczewski J, Spencer RH, Garsky VM, Liang A, Leitl MD, Cato MJ, Cook SP, Kane S, Urban MO. Reversal of acid-induced and inflammatory pain by the selective ASIC3 inhibitor, APETx2. Br J Pharmacol. 2010;161:950-60.

31. Dussor G. ASICS as therapeutic targets for migraine. Neuropharmacol. 2015;94:64-71.

32. Omori M, Yokoyama M, Matsuoka $Y$, Kobayashi $H$, Mizobuchi S, Itano $Y$, Morita $\mathrm{K}$, Ichikawa $\mathrm{H}$. Effects of selective spinal nerve ligation on acetic acid-induced nociceptive responses and ASIC3 immunoreactivity in the rat dorsal root ganglion. Brain Res. 2008;1219:26-31.

33. Wang X, Li WG, Yu Y, Xiao X, Cheng J, Zeng WZ, Peng Z, Xi Zhu M, Xu TL. Serotonin facilitates peripheral pain sensitivity in a manner that depends on the nonproton ligand sensing domain of ASIC3 channel. J Neurosci. 2013; 33:4265-79.

34. Qiu F, Qiu CY, Liu YQ, Wu D, Li JD, Hu WP. Potentiation of acid-sensing ion channel activity by the activation of $5-\mathrm{HT}(2)$ receptors in rat dorsal root ganglion neurons. Neuropharmacol. 2012;63:494-500.

35. Gan X, Wu J, Ren C, Qiu CY, Li YK, Hu WP. Potentiation of acid-sensing ion channel activity by peripheral group I metabotropic glutamate receptor signaling. Pharmacol Res. 2016;107:19-26.

36. Ren C, Gan X, Wu J, Qiu CY, Hu WP. Enhancement of acid-sensing ion channel activity by metabotropic P2Y UTP receptors in primary sensory neurons. Purinergic Signal. 2016;12:69-78.

37. Amadesi S, Cottrell GS, Divino L, Chapman K, Grady EF, Bautista F, Karanjia R, Barajas-Lopez C, Vanner S, Vergnolle N, Bunnett NW. Protease-activated receptor 2 sensitizes TRPV1 by protein kinase Cepsilon- and A-dependent mechanisms in rats and mice. J Physiol. 2006:575:555-71.

38. Gavva NR, Tamir R, Qu Y, Klionsky L, Zhang TJ, Immke D, Wang J, Zhu D, Vanderah TW, Porreca F, et al. AMG 9810 [(E)-3-(4-t-butylphenyl)-N-(2,3dihydrobenzo[b][1,4] dioxin-6-yl)acrylamide], a novel vanilloid receptor 1 (TRPV1) antagonist with antihyperalgesic properties. J Pharmacol Exp Ther. 2005:313:474-84

39. Diochot S, Baron A, Rash LD, Deval E, Escoubas P, Scarzello S, Salinas M, Lazdunski M. A new sea anemone peptide, APETx2, inhibits ASIC3, a major acid-sensitive channel in sensory neurons. EMBO J. 2004;23:1516-25.
40. Blanchard MG, Rash LD, Kellenberger S. Inhibition of voltage-gated $\mathrm{Na}(+)$ currents in sensory neurones by the sea anemone toxin APETx2. Br J Pharmacol. 2012;165:2167-77.

41. Mamet J, Baron A, Lazdunski M, Voilley N. Proinflammatory mediators, stimulators of sensory neuron excitability via the expression of acid-sensing ion channels. J Neurosci. 2002;22:10662-70.

42. Deval E, Salinas M, Baron A, Lingueglia E, Lazdunski M. ASIC2b-dependent regulation of ASIC3, an essential acid-sensing ion channel subunit in sensory neurons via the partner protein PICK-1. J Biol Chem. 2004;279:19531-9.

43. Lingueglia E. Acid-sensing ion channels in sensory perception. J Biol Chem. 2007;282:17325-9.

44. Wang S, Dai Y, Kobayashi K, Zhu W, Kogure Y, Yamanaka H, Wan Y, Zhang W, Noguchi K. Potentiation of the P2X3 ATP receptor by PAR-2 in rat dorsal root ganglia neurons, through protein kinase-dependent mechanisms, contributes to inflammatory pain. Eur J Neurosci. 2012;36:2293-301.

45. Wu L, Oshima T, Shan J, Sei H, Tomita T, Ohda Y, Fukui H, Watari J, Miwa H. PAR-2 activation enhances weak acid-induced ATP release through TRPV1 and ASIC sensitization in human esophageal epithelial cells. Am J Physiol Gastrointest Liver Physiol. 2015;309:G695-702.

46. Kweon HJ, Suh BC. Acid-sensing ion channels (ASICs): therapeutic targets for neurological diseases and their regulation. BMB Rep. 2013;46:295-304.

47. Seeliger S, Derian CK, Vergnolle N, Bunnett NW, Nawroth R, Schmelz M, Von Der Weid PY, Buddenkotte J, Sunderkotter C, Metze D, et al. Proinflammatory role of proteinase-activated receptor-2 in humans and mice during cutaneous inflammation in vivo. FASEB J. 2003;17:1871-85.

48. Rothmeier AS, Ruf W. Protease-activated receptor 2 signaling in inflammation. Semin Immunopathol. 2012;34:133-49.

\section{Submit your next manuscript to BioMed Central and we will help you at every step:}

- We accept pre-submission inquiries

- Our selector tool helps you to find the most relevant journal

- We provide round the clock customer support

- Convenient online submission

- Thorough peer review

- Inclusion in PubMed and all major indexing services

- Maximum visibility for your research

Submit your manuscript at www.biomedcentral.com/submit

Biomed Central 